19 Revue d'histoire du XIXe siècle

Société d'histoire de la révolution de 1848 et des

révolutions du XIXe siècle

$22 \mid 2001$

Autour de Décembre 1851

\title{
Avertissement de réédition
}

\section{OpenEdition}

\section{Journals}

Electronic version

URL: http://journals.openedition.org/rh19/253

DOI: $10.4000 /$ rh 19.253

ISSN: $1777-5329$

\section{Publisher}

La Société de 1848

\section{Printed version}

Date of publication: 1 June 2001

ISSN: 1265-1354

Electronic reference

"Avertissement de réédition », Revue d'histoire du XIXe siècle [Online], 22 | 2001, Online since 04 September 2008, connection on 19 April 2019. URL : http://journals.openedition.org/rh19/253 ; DOI : $10.4000 /$ rh19.253

This text was automatically generated on 19 April 2019

Tous droits réservés 


\section{Avertissement de réédition}

\section{ABSTRACTS}

A l'occasion de ce numéro consacré au coup d'État du 2 décembre, nous mettons en ligne l'intégralité du numéro de décembre 1951 de la revue 1848 - Revue des révolutions contemporaines. Les textes sont conformes à ceux publiés alors, à l'exception de quelques coquilles typographiques corrigées. Une version téléchargeable de chaque article au format pdf est également proposée, qui indique la pagination originale. Le travail de numérisation, mise en mode texte, correction et mise en page a été effectué par Laurent Clavier. 